\title{
Evaluasi Perbaikan Kebijakan Penegakan Hukum Pertambangan Perspektif Genealogi Hukum dan Kuasa di Kabupaten Bangka Selatan
}

\author{
Faisal $^{1}$, Ndaru Satrio ${ }^{2}$, Komang Jaka Ferdian ${ }^{3}$ \\ ${ }^{1}$ Fakultas Hukum Universitas Bangka Belitung, E-mail: progresif_lshp@yahoo.com \\ ${ }^{2}$ Fakultas Hukum Universitas Bangka Belitung, E-mail: satrio.ndaru9@gmail.com \\ ${ }^{3}$ Fakultas Ilmu Sosial dan Ilmu Politik Universitas Bangka Belitung, E-mail : \\ komangikf@gmail.com
}

\begin{tabular}{l}
\hline Info Artikel \\
\hline Masuk: 28 Juni 2020 \\
Diterima: 27 September 2020 \\
Terbit: 30 September 2020 \\
Keywords: \\
Evaluation Model; Policy \\
Improvement; Mining Law \\
Enforcement; The Genealogy of \\
Law and Power \\
\\
\\
Faisal \\
E-mail: \\
progresif_lshp@yahoo.com \\
\\
Kata kunci: \\
Model Evaluasi; Perbaikan \\
Kebijakan; Penegakan Hukum \\
Pertambangan; Genealogi \\
Hukum dan Kuasa. \\
\end{tabular}

\begin{abstract}
Mining has become an attractive and sensitive sector for the public in South Bangka Regency. This research is aimed to analyze the legal genealogy and power for evaluation and improvement of mining law enforcement policies in South Bangka Regency and to analyze the model evaluation and improvement of mining law enforcement policies in South Bangka Regency). This study uses a qualitative method with a socio-legal approach, focuses on the self-concept interaction patterns, the concept of action, the concept of interaction, the concept of objects, and the concept of collective action in the community, to answer the question of the urgency of tracing legal genealogy and power for evaluation and improvements to mining law enforcement policies in South Bangka Regency. The research results suggested that the Geneology study involved revealing the relationship between law and power in the mining law enforcement policies in the South Bangka Regency which are still deemed incompatible with the principles of equality before the law, legal certainty, and legal justice. The evaluation model and improvement of mining law enforcement policies are an important part of improving mining law enforcement policies in South Bangka Regency which are based on the basic idea of state responsibility and environmental sustainability.
\end{abstract}

\begin{tabular}{l}
\hline Abstrak \\
\hline Pertambangan menjadi sektor yang menarik sekaligus sensifitif \\
bagi publik di Kabupaten Bangka Selatan. Tujuan penelitian ini \\
untuk menganalisa geneologi hukum dan kuasa untuk evaluasi \\
dan perbaikan Kebijakan penegakan hukum pertambangan di \\
Kabupaten Bangka Selatan serta untuk menganalisis model \\
evaluasi dan perbaikan Kebijakan penegakan hukum \\
pertambangan di Kabupaten Bangka Selatan. Penelitian ini \\
menggunakan metode kualitatif dengan pendekatan socio-legal, \\
yang menujukan pusat perhatian pada pola interaksi konsep diri, \\
konsep perbuatan, konsep interaksi, konsep objek, dan konsep aksi \\
bersama dalam warga masyarakat, untuk menjawab \\
permasalahan Urgensi Penelusuran Genealogi Hukum dan \\
Kuasa Untuk Evaluasi Dan Perbaikan Kebijakan Penegakan \\
Hukum Pertambangan di Kabupaten Bangka Selatan. Hasil
\end{tabular}




\section{DOI:}

10.24843/JMHU.2020.v09.i03. p02

penelitian menunjukkan bahwa, studi Geneologi terlibat dalam mengungkap relasi hukum dan kuasa dalam kebijakan penegakan hukum pertambangan di Kabupaten Bangka Selatan yang masih dirasakan tidak sesuai dengan prinsip-prinsip persamaan di depan hukum, kepastian hukum, dan keadilan hukum. Model evaluasi dan perbaikan kebijakan penegakan hukum pertambangan merupakan bagian penting untuk memperbaiki kebijakan penegakan hukum pertambangan di Kabupaten Bangka Selatan yang berpijak pada ide dasar tanggung jawab negara dan kelestarian serta keberlanjutan lingkungan.

\section{Pendahuluan}

Kabupaten Bangka Selatan, Provinsi Kepulauan Bangka Belitung merupakan Kabupaten yang dibentuk pada tanggal 25 Februari 2003 berdasarkan UndangUndang Nomor 5 Tahun 2003. Wilayah administratif Kabupaten Bangka Selatan berbatasan langsung dengan Kabupaten Bangka, Kabupaten Bangka Tengah, dan Kota Pangkal Pinang. Tujuan awal pembentukan Kabupaten Bangka Selatan bukan hanya terkait dengan pengembangan wilayah Provinsi, tetapi juga terkait dengan upaya mempercepat pembangunan daerah serta agar terciptanya pelayanan yang efektif dan efisien bagi masyarakat yang berada di daerah tersebut.

Kabupaten Bangka Selatan merupakan daerah yang relatif aman dan nyaman untuk bermukim. Kendatipun demikian, pernah terjadi konflik antara pemerintah daerah dengan pihak penambang yang dipicu oleh tindakan penertiban tambang inkonvensional (TI) oleh Polisi Pamong Praja dengan cara membakar areal pertambangan yang sedang beroperasi di wilayah Kabupaten Bangka Selatan.

Pihak Polisi Pamong Praja bukannya tanpa alasan membakar perlengkapan tambang tersebut. Sebagaimana diungkap oleh Kepala Bidang Ketertiban dan Ketentraman Masyarakat Satuan Polisi Pamong Praja Untung Sridadi, penertiban dilakukan sebanyak 12 (dua belas) kali selama tahun 2019, tetapi tidak mendapat respon baik dari warga yang memiliki perlengkapan TI. ${ }^{1}$ Selain itu, Polisi Pamong Praja beranggapan bahwa aktivitas tambang yang dilakukan oleh warga berada pada kawasan krusial sehingga aparatnya mengambil tindakan tegas dengan melakukan pembakaran.

Adapun dampak lain dari aktivitas pertambangan sehingga perlu ditindak yaitu adanya pencemaran limbah dari aktivitas pertambangan yang mengakibatkan terancamnya kebun karet milik warga Toboali, tepatnya di kawasan Parittiga. Masyarakat beranggapan bahwasanya tingkat pencemaran limbah tambang cukup parah. Kebun karet milik warga seluas 1 (satu) hektar terendam air yang bercampur dengan lumpur limbah pertambangan. Kedalaman air yang bercampur lumpur limbah pertambangan mencapai selutut orang dewasa bahkan di beberapa areal perkebunan warga ada yang terendam mencapai pinggang orang dewasa. Pariadi, seorang warga Sukadamai menyebutkan bahwasanya kebun mereka terendam air bercampur lumpur

1Jhoni Kurniawan. (2020) Tak Indahkan Peringatan, Satpol PP Bangka Selatan Tak Segan Bakar TI Ilegal, https://bangka.tribunnews.com/2020/03/09/tak-indahkan-peringatan-satpol-ppbangka-selatan-tak-segan-bakar-ti-ilegal, diakses tanggal 10 Maret 2020 
yang berasal dari aktivitas pertambangan yang dilakukan tidak jauh dari lokasi perkebunan warga. ${ }^{2}$

Pertambangan Inkonvensional (TI) yang beraktivitas bukan hanya berdampak pada kondisi ekonomi, namun terindikasi pula menimbulkan perubahan sosial masyarakat sekitar areal pertambangan. Pertambangan tersebut menimbulkan eskalasi konflik antara perusahaan tambang dengan masyarakat, berubahnya kondisi masyarakat agraris menjadi masyarakat tambang serta berdampak buruk bagi lingkungan yang dapat merubah kondisi ekologis di areal pertambangan. ${ }^{3}$ Situasi ini mempertegas pentingnya pengelolaan sumber daya mineral yang menjadi kekayaan alam tidak terbarukan untuk kemudian dikuasai oleh Negara guna mewujudkan kemakmuran bagi masyarakat serta pemanfaatan secara optimal oleh negara untuk masa sekarang dan masa yang akan dating. ${ }^{4}$

Meningkatnya kegiatan pembangunan untuk memenuhi kebutuhan hidup manusia yang terus meningkat dan berkembang, menyebabkan peningkatan permintaan Sumber Daya Alam (SDA) yang ketersediaanya terbatas dan tidak merata menyebabkan daya dukung lingkungan hidup terganggu dan daya tampung lingkungan hidup menurun. ${ }^{5}$ Dewasa ini pertambangan menjadi sektor yang menarik sekaligus sensifitif bagi publik. Menarik karena berkontribusi terhadap Penerimaan Negara dan kian disorot bila harga komoditas dunia melonjak, tetapi juga sensitif karena ekses negatif terhadap lingkungan serta pandangan bahwa pertambangan belum memberi keuntungan maksimal bagi seluruh stakeholder seperti yang diharapkan, bahkan dalam ranah penegakan. ${ }^{6}$

Lebih lanjut peran serta masyarakat dinilai sangat penting dan tidak boleh diabaikan hal tersebut berkenaan dengan pemberian informasi kepada pemerintah mengenai masalah-masalah dan konsekuensi yang timbul dari tindakan-tindakan yang direncanakan pemerintah. Dengan demikian pemerintah dapat mengetahui ada berbagai kepentingan yang dapat terkena tindakan tersebut dan perlu diperhatikan, ${ }^{7}$ Peran serta masyarakat perlu perhatian khusus dalam rangka pelaksanaan aktivitas pertambangan oleh Pemerintah.

Pada aktifitas pertambangan di wilayah yang sudah ditentukan, pembinaan dan supervisi penyelenggaraan pengelolaan pertambangan mineral dan batubara

2 Aston. (2019). Submerged by TI Waste, Hundreds of Pariadi's Rubber Trees Threatened to Death. URL: https://wowbabel.com/2019/12/26/terendam-limbah-ti-ratusan-pohon-karet-milikpariadi-terancam-mati, diakses tanggal 07 Maret 2020.

3 Butar, F. B. (2010). Penegakan Hukum Lingkungan di Bidang Pertambangan. Yuridika, 25(2), 151-168, http:/ / dx.doi.org/10.20473/ydk.v25i2.252, p.153.

${ }^{4}$ Lihat: Supramono, G. (2012). Hukum Pertambangan Mineral dan Batu Bara di Indonesia. Rineka Cipta. p. 2.

${ }^{5}$ Prianto, Y., Djaja, B., Rasji, S. H., \& Gazali, N. B. (2019). Penegakan Hukum Pertambangan Tanpa Izin Serta Dampaknya Terhadap Konservasi Fungsi Lingkungan Hidup. Bina Hukum Lingkungan, 4(1), 1-20. DOI: http://dx.doi.org/10.24970/bhl.v4i1.80, p. 6.

${ }^{6}$ Sembiring, S. F. (2009). Jalan baru untuk tambang: mengalirkah berkah bagi anak bangsa. Elex Media Komputindo. p. 175.

7 Rahayu, D. P., \& Faisal, J. C. (2019). Rekonstruksi Partisipasi Masyarakat Dalam Perizinan Pertambangan Rakyat Berbasis Nilai Kearifan Lokal (Studi Kasus Izin Pertambangan Rakyat di Kabupaten Belitung Timur). In Prosiding Seminar Hukum dan Publikasi Nasional (Serumpun) (Vol. 1, No. 1, pp. 446-457). http://prosiding.fh.ubb.ac.id/index.php/prosidingserumpun/article/view/49, p. 552. 
dilakukan oleh pemerintah daerah setempat. ${ }^{8}$ Penelusuran historikalitas pemahaman penegakan hukum pertambangan menjadi penting untuk diteliti dalam model kronologis, karena manusia dalam bertindak tidak hanya dituntut untuk berbuat menurut aturan-aturan hukum formal, tetapi juga menurut kearifan hukum lokal masyarakat setempat. Seperti dikutip oleh Wayne Parsons et.al

"In an era in which policy-making was increasingly being framed by the metaphor of steering, a key question which academics and practitionersfocusedonwas:howcouldpolicymaking be redesigned so as to enhance its strategicrolein(andover)acomplexanddiverse range of actors, levels, institutions, relation- ships, networks and organisational forms? If government was to steer, it had to be able to map and utiliseand manage policy-relevant knowledge.Themanagementofknowledgeand organisational learning, rather than just discreetly focused data on society or the economy, thus became critical to the ability of policymakerstoimprovetheir capacity tomake and implement policy"9.

Atas alasan itu peneliti sangat tertarik untuk melakukan penelitian mengenai mengapa perlu melibatkan studi genealogi hukum dan kuasa dalam rangka evaluasi dan perbaikan kebijakan penegakan hukum pertambangan di Kabupaten Bangka Selatan dan bagaimana model evaluasi dan perbaikan kebijakan penegakan hukum pertambangan. Penelitian ini bertujuan untuk menganalisa geneologi hukum dan kuasa untuk evaluasi dan perbaikan kebijakan penegakan hukum pertambangan di Kabupaten Bangka Selatan serta untuk menganalisa model evaluasi dan perbaikan kebijakan penegakan hukum pertambangan (studi genealogi hukum dan kuasa di Kabupaten Bangka Selatan).

\section{Metode Penelitian}

Metode penelitian yang digunakan dalam penelitian ini yaitu metode penelitian kualitatif dengan menggunakan pendekatan socio-legal. Pendekatan socio-legal merupakan metode interdisipliner dalam studi hukum dimana penggunaan analisa hukum normatif (norma-norma hukum, yuridis) dipadukan dengan pendekatan ilmu non-hukum dalam hal ini Ilmu Sosial sehingga memperkaya pendekatan metodologi hukum. Data yang digunakan adalah data primer yang diperoleh melalui wawancara terhadap sejumlah informan dan data sekunder yang didapatkan melalui studi literatur. ${ }^{10}$

Pusat perhatian akan ditujukan pada pola interaksi konsep diri, konsep perbuatan, konsep interaksi, konsep objek, dan konsep aksi bersama dalam warga Masyarakat Kabupaten Bangka Selatan yang dikontekstualisasikan terhadap sistem nilai, norma dan makna yang dipercayai dan dijalankan secara turun-temurun, dimana hal itu akan dianalisa dan dijelaskan dengan menggunakan paradigma interaksionisme simbolik. Informasi yang didapat akan dibandingkan dengan tahapan di atas dengan tujuan agar memperoleh data yang valid.

${ }^{8}$ Rahayu, D. P., \& Faisal, F. (2020). Legal of Permission Folk Mining in Indonesia. Wacana Hukum, 26(1), 49-54. DOI: http:/ / dx.doi.org/10.33061/1.wh.2020.26.1.3630, p. 2.

9 Parsons, W. (2004). Not just steering but weaving: Relevant knowledge and the craft of building policy capacity and coherence. Australian journal of public administration, 63(1), 43-57. DOI: https:/ / doi.org/10.1111/j.1467-8500.2004.00358.x, p. 4

${ }^{10}$ Rahayu, D. P., Pujirahayu, E. W., \& Samekto, F. A. (2018, July). Institutional Territory on Folk Mining in Indonesia. In IOP Conference Series: Earth and Environmental Science (Vol. 175, No. 1, p. 012186). IOP Publishing. DOI: https://doi.org/10.1088/1755-1315/175/1/012186, p. 3 


\section{Hasil dan Pembahasan}

3.1. Urgensi Penelusuran Genealogi Hukum dan Kuasa untuk Evaluasi dan Perbaikan Kebijakan Penegakan Hukum Pertambangan di Kabupaten Bangka Selatan

Secara etimologi genealogi berasal dari dua suku kata yaitu genea (keturunan) dan ogos (pengetahuan). Genealogi dapat dikatakan sebagai kajian tentang penelusuran jalur keturunan serta sejarahnya. Dalam hal ini genealogi erat kaitannya dengan studi antropologi yang mencoba mengkaji sejarah dalam perkembangan zaman. Untuk melihat lebih ke dalam memerlukan metode ontologi yang dapat digunakan untuk menjawab keberadaan (eksistensi) suatu permasalahan tertentu serta tujuannya untuk mengungkapkan keberadaan (yang ada) sehingga sering disebut sebagai teori tentang ada dan berada. ${ }^{11}$

Teori genealogi dari Michel Foucault akan digunakan sebagai pintu masuk pemaknaan kebijakan penegakan hukum pertambangan. Genealogi banyak bermanfaat dalam ikhtiar ini, karena ia merupakan proses pendokumentasian yang cerdas, sangat teliti dan sabar, yang bertujuan utama untuk melakukan pembongkaran terus-menerus atas struktur pengetahuan. ${ }^{12}$

Definisi genealogi yaitu proses menganalisa dan menyingkap hubungan sejarah antara kebenaran, pengetahuan, dan kekuasaan, dimana pengetahuan dan kebenaran dihasilkan melalui perjuangan lalu dinyatakan sebagai abadi dan universal. Genealogi kebijakan penegakan hukum pertambangan akan dipahami sebagai konstruksi sosial yang dihasilkan dari perjuangan dan pertarungan serta menghasilkan relasi kebenaran, pengetahuan dan kekuasaan.

Relevansi terhadap fokus kajian, bagaimana memahami penegakan hukum pertambangan sebagai mekanisme yang mengatur perbuatan bertindak dalam pendefinisian kebijakan hukum pertambangan. Penegak hukum sering kali kesulitan untuk memisahkan konsep normatif hukum, baik dari segi hukum administrasi, perdata dengan hukum pidana yang dalam kasus pertambangan berkaitan erat dengan kondisi sosial.

Ketentuan-ketentuan yang tertuang di dalam Undang-undang Nomor 4 Tahun 2009 tentang Pertambangan Mineral dan Batu Bara dan Undang-undang Nomor 32 Tahun 2009 Tentang Perlindungan dan Pengelolaan Lingkungan Hidup perlu dicermati oleh seluruh pelaku usaha pertambangan. Munculnya aturan baru dalam undang-undang tersebut memberikan kewenangan besar kepada Kementerian Lingkungan Hidup yang dapat memberikan izin di atas izin lainnya. Kewenangan inilah yang kemudian memicu munculnya kepanikan bagi kalangan industri pertambangan karena izin lingkungan seolah-olah dijadikan prasyarat untuk memperoleh izin usaha dana atau

11 Isdiyanto, I. Y. (2018). Menakar "Gen" Hukum Indonesia Sebagai Dasar Pembangunan Hukum Nasional. Jurnal Hukum \& Pembangunan, 48(3), 589-611. DOI: http://dx.doi.org/10.21143/jhp.vol48.no3.1747, p. 591

12 Philpott, S. (2007). Meruntuhkan Indonesia "Politik Postkolonial dan Otoritarianisme", Yogyakarta, LKIS, p. 26 
kegiatan pertambangan Minerba. ${ }^{13}$ Pasal 158 Undang-undang Nomor 4 Tahun 2009 Tentang Pertambangan Mineral dan Batu Bara menyebutkan bahwa:

"Setiap orang yang melakukan usaha penambangan tanpa IUP,IPR atau IUPK sebagaimana dimaksud dalam Pasal 37, Pasal 40 ayat (3), Pasal 18, Pasal 67 ayat (I), Pasal 74 ayat (1) atau ayat (5) dipidana dengan pidana penjara paling lama 10(sepuluh) tahun dan denda paling banyak Rp 10.000.000,00 (SepuluhMilyar Rupiah)".

Genealogi merupakan sejarah yang ditulis dalam terang penglihatan dan kepedulian (concern) masa kini. Pandangan Michel Foucault, sejarah selalu ditulis dari perspektif masa kini. Sejarah merupakan pemenuhan atas sebuah kebutuhan masa kini. Fakta bahwa masa kini selalu berada dalam sebuah proses transformasi mengandung implikasi bahwa masa lalu haruslah terus menerus dievaluasi ulang ${ }^{14}$.

Genealogi tidak berpretensi untuk kembali ke masa lalu dengan tujuan untuk memulihkan sebuah kontinuitas yang tak terputus. Justru sebaliknya, "genealogi berusaha mengidentifikasi hal-hal yang menyempal (accident), mengidentifikasi penyimpangan-penyimpangan yang kecil (the minute deviations)". Genealogi memfokuskan diri pada retakan-retakan, pada kondisi-kondisi sinkronik (perubahanperubahan saat-saat tertentu) dan tumpang tindihnya pengetahuan yang bersifat akademis dengan kenangan-kenangan yang bersifat lokal ${ }^{15}$.

Dalam konteks penelitian ini, pengetahuan yang para penambang miliki, yaitu masalah rentang pengetahuan, bahwa kebutuhan ekonomi merupakan prioritas sehingga menimbulkan aktivitas pertambangan dengan mengikuti pola penambangan yang sudah dilakukan oleh penambang terdahulu. Konteks pertambangan di sini banyak yang tidak mempunyai izin, masalah kultural karena kebutuhan ekonomi dan awam hukum. Merujuk pendapat Ahmad Redi, aspek pertumbuhan ekonomi (economic development) keadilan dan lingkungan hidup menjadi satu kesatuan yang terkonvergensi secara utuh dalam kebijakan dan pelaksanaan pengelolaan sumberdaya mineral dan batubara ${ }^{16}$.

Kebenaran yang dipahami oleh masyarakat khususnya para penambang rakyat yaitu ketika penambangan dilakukan tidak saling mengganggu wilayah menambang pada kelompok masing-masing penambang. Cara menambangnya dalam perspektif mereka sekaligus cara pelestarian lingkungan pasca menambang, misalnya kaitan dengan dampak penambangan sesuai dengan kebenaran yang dipahami mereka, yaitu bahwa penambangan yang mereka lakukan tidak berbahaya bagi lingkungan. Selama penambangan mereka tidak didatangi petugas, berarti pemahaman mereka adalah penambangan merupakan hal yang benar.

${ }^{13}$ Mai, M., \& Saputra, E. B. (2018). Penegakan Hukum Terhadap Tindak Pidana Pertambangan Batuan Non Logam Pada Tanah Hak Milik Masyarakat (Studi Pada Satreskrim Polres Kerinci). UNES Law Review, 1(1), 70-80. DOI: https:/ / doi.org/10.31933/law.v1i1.7, p. 71

${ }^{14}$ Latif, Y. (2013). Genealogi Intelegensia Pengetahuan dan Kekuasaan Intelegensia Muslim Indonesia Abad XX. Jakarta: Kencana, p. 07.

15 Ibid.

16 Redi, A. (2016). Dilema Penegakan Hukum Penambangan Mineral Dan Batubara Tanpa Izin Pada Pertambangan Skala Kecil. Jurnal Rechts Vinding: Media Pembinaan Hukum Nasional, 5(3), 399-420. DOI: http:/ / dx.doi.org/10.33331/rechtsvinding.v5i3.152, p. 401 
Kebenaran dan pengetahuan yang bermukim pada penambang yang tergambar dalam kognitif mereka ternyata terlegitimasi oleh kekuasaan di sana, yaitu pemerintah di Kabupaten Bangka Selatan. Kekuasaan penegakan hukum dan kekuasaan administrasi perizinan beradaptasi dengan kebenaran dan pengetahuan di masyarakat tersebut. Kekuasaan itu akhirnya membentuk fleksibilitas terkait pelaksanaan, hal ini terbukti saat Pariadi melakukan pelaporan, Polisi justru kemudian melakukan mediasi dengan penambang dan Mitra PT. Timah. Hal ini mengindikasikan pemahaman Polisi tersandera oleh penambang, bahwa penambang membutuhkan hajat hidup "makan" untuk keberlanjutan hidup. Jadi penegakan hukum tidak bergerak pada prosedur normatif saja, akan tetapi ada pelbagai aspek lainnya. Mekanisme perizinan itu juga menyesuaikan diri dengan pengetahuan dan kebenaran pada masyarakat tambang. Konteksnya adalah pada masalah teknis pengaturan, yaitu segala sesuatu prosedur dan syarat itu yang sebenarnya ditempuh secara ketat beserta tahapan ternyata di lapangan menjadi fleksibel atau longgar begitu juga dalam hal prasarat yang harus dipenuhi dengan situasi dan kondisi yang dilonggarkan.

Haryatmoko mendefiniskan genealogi sebagai proses menganalisa dan menyingkap hubungan sejarah antara kebenaran, pengetahuan, dan kekuasaan, dimana pengetahuan dan kebenaran dihasilkan melalui perjuangan lalu dinyatakan sebagai abadi dan universal ${ }^{17}$. Cara kerja genealogi bertumpu pada upaya penelusuran awal dari sebuah pengetahuan dan kemudian menjelaskan segala hal yang terkait dapat terbentuk untuk menjawab semua kebutuhan pengetahuan, kemudian penelusuran tersebut menjelaskan bagaimana dapat diganti/ dimodifikasi serta seluas apa semua itu diterapkan ${ }^{18}$.

Genealogi banyak bermanfaat dalam ikhtiar ini, karena ia merupakan proses pendokumentasian yang cerdas, sangat teliti dan sabar, yang bertujuan utama untuk "melakukan pembongkaran terus-menerus atas struktur pengetahuan. ${ }^{19}$ Genealogi memfokuskan diri pada diskursus-diskursus yang berlaku dan membongkar sistem nilai dengan memahami semua yang dianggap alamiah dan/atau yang sudah mapan. Pemahaman umum tentang sejarah, yang dipengaruhi oleh Hegel, memandang masa sekarang (the present) sebagai kelanjutan makna yang berasal dari masa lalu: jejak dari apa yang dipahami sebagai subtansi di masa lalu ditemukan pada masa sekarang. Tetapi, genealogi berbeda dengan itu, genealogi memperlakukan pengetahuan bukan sebagai proses pencerahan yang akumulatif, melainkan sebagai perwujudan kekuasaan, sebagai bentuk penalukkan.

Genealogi bertujuan untuk menjelaskan operasi kekuasaan dalam praktik pengetahuan. Kebijakan penegakan hukum pertambangan merupakan perwujudan kekuasaan yang sudah terinstitusionalisasi dalam konstruksi kebijakan hukum pertambangan. Absolutisme paham yang dibangun selalu mengidentifikasi konstruksi kebijakan hukum pertambangan memiliki daya berlaku universal.

Kebijakan hukum pertambangan dengan pengertian yang demikian, justru telah menjadi pengetahuan yang mapan. Konsep kekuasaan yang ada dibalik konstruksi kebijakan hukum pertambangan telah menjadi ilmu pengetahuan, akan dibongkar

17 Haryatmoko, J. (2016). Etika politik dan kekuasaan. Kompas. p. 249.

${ }^{18}$ Hefni, W. (2018). Genealogi Studi Hukum Islam di Perguruan Tinggi Keagamaan Islam Indonesia. Al-Ihkam: Jurnal Hukum dan Pranata Sosial,13(1), 226-230. DOI: http://dx.doi.org/10.19105/al-ihkam.v13i1.1788, p. 208

${ }_{19}$ Philpott, S. (2007). Loc. cit. 
serta ditelusuri oleh genealogi. Jika dikaitkan dengan kebijakan penegakan hukum pertambangan, hal ini juga berada pada ranah kebijakan public. Kraft dan Furlong mengonsepkan kebijakan publik sebagai berikut, "A course of government action (or inaction) taken in response to social problems. Social problems are conditions the public widely perceives to be unacceptable and therefore requiring intervention" 20 . Dengan melihat pendapat tersebut maka pada dasarnya hukum dan sebuah kebijakan publik perlu dibangun dengan melibatkan pemerintah dan masyarakat yang saling berkomunikasi guna mendapatkan produk kebijakan/hukum yang tidak bertentangan dengan asas keadilan.

Hubungan kekuasaan dan pengetahuan ini diperlihatkan Foucault dalam studi geneologisnya mengenai mikro-fisika dari kekuasaan. ${ }^{21}$ Studi ini mengatakan bahwa kekuasaan dilaksanakan dalam tubuh bukan sebagai milik, melainkan sebagai strategi yang menyebar dalam masyarakat modern. Kekuasaan Menurut Foucault merupakan keadaan dimana masyarakat tidak memahami secara pasti karena kekuasaan ditempatkan pada situasi strategis yang rumit sehingga masyarakat sulit untuk menangkap makna kekuasaan. Dalam relasi kuasa, tentu saja terdapat pihak yang di atas dan di bawah, di pusat dan di pinggir serta di dalam dan di luar. Hal tersebut pada dasarnya menurut Foucault kekuasaan tidak berjalan dengan normatif seperti itu akan tetapi kekuasaan dapat menyebar, terpencar dan hadir di mana-mana.

Legalitas hukum pertambangan merupakan peneguhan wacana pengetahuan modern yang terlahir melalui kuasa kebijakan hukum pertambangan. Penelusuran terhadap legalitas hukum pertambangan dalam kajian yang dilakukan peneliti, hendak melakukan koreksi atas absolutisme kebenaran yang sudah terlanjur mapan. Legalitas hukum pertambangan yang di klaim membawa spirit kekuasaan pengetahuan modern, bila merujuk Foucault, justru menimbulkan kebijakan yang perlu mengalami perbaikan dan evaluasi dalam rangka membangun kesadaran baru untuk menawarkan model kebijakan penegakan hukum pertambangan yang memperhatikan aspek ekologis dan kearifan lokal.

Anggapan kekuasaan yang sah selalu hadir dari atas atau kekuasaan negara, bagi Foucault hal itu ialah paham kekuasaan tradisional karena kekuasaan dipahami sebagai akumulasi otonom, dan tidak mengakui yang lain. Padahal, jika melihat identitas hukum nasional, dinamika nilai-nilai yang hidup di masyarakat lebih bernilai kekuasaan yang otentik dan terpelihara dalam ragam kultural.

\subsection{Model Evaluasi dan Perbaikan Kebijakan Penegakan Hukum Pertambangan (Studi Genealogi Hukum dan Kuasa di Kabupaten Bangka Selatan)}

Sejarah legalitas hukum pertambangan, menjadi legitimasi yang bertujuan mengawasi kekuasaan atas kekuasaan kebijakan pertambangan. Menjadi persoalan ketika legalitas hukum pertambangan tersebut tanpa pemaknaan (evaluasi dan perbaikan) atas identitas kultural dan pemetaan terhadap kelestarian lingkungan serta aspek

${ }^{20}$ Budiman, S. (2017). Analisis Hubungan antara Hukum dan Kebijakan Publik: Studi Pembentukan UU No. 14 Tahun 2008. Jurnal Ilmiah Kebijakan Hukum,11(2), 109-119. DOI: http://dx.doi.org/10.30641/kebijakan.2017.V11.109-119, p. 110

${ }^{21}$ A. Widyarsono, (1999) Hubungan Kuasa dan Pengetahuan Menurut Foucault Jurnal Filsafat Driyarkara, Tahun XXI, No. 4. p. 11 
kesejahteraan ekonomi. Secara teoritis, Kebijakan publik dapat dijelaskan harus mencakup hal umum yang kemudian dilegalisasikan dalam bentuk hukum dan pada dasarnya hukum merupakan produk dari kebijakan. Penjelasan tersebut menggambarkan bahwasanya hukum dan kebijakan publik pada tataran praktis tidak dapat dipisahkan, keduanya dapat dikatakan berjalan seiring dengan prinsip saling mengisi. ${ }^{22}$

Hanya dengan melihat sejarah, memahami logika diskursus yang bekerja dan untuk kemudian mengkritisinya dalam artian mempertanyakan terus-menerus. Merujuk pandangan Foucault, upaya membaca sejarah disebut sebagai bagian tekhnikalisasi diri dalam rangka subjektifikasi subjek. Berlatar maksud ini pulalah penelusuran sejarah legalitas hukum pertambangan dalam bingkai kebijakan perlu di rekonstruksi kembali dengan melalui evaluasi dan perbaikan. Menggunakan genealogi, peneliti coba mengurai diskursus yang berkembang sebagai bahan menumbuhkan kekritisan sehingga tercipta "subjek yang aktif " yakni, subjek yang terlibat relasi dielektis dengan serangkaian pengetahuan (episteme) yang membentuknya.

Alasan inilah, menurut peneliti betapa pentingnya genealogi mengungkap legalitas hukum pertambangan yang begitu kuat masih berada pada lingkaran pengetahuan historisitas pemikiran yang dibangun tidak dalam kerangka yang integral. Realitas kebijakan penegakan hukum pertambangan terbelenggu dengan kepentingan komoditas kapital semata-mata. Genealogi akan berusaha menyingkap kebenaran yang telah terlanjur mapan dalam legalitas hukum pertambangan dengan mendefinisikan kembali hakikat dan sejarahnya tentu tidak terjebak dengan ego subjek historis.

Genealogi Foucault akan member penjarakan yang massif untuk mengungkap historisitas legalitas hukum pertambangan tanpa harus terbebani dengan identitas subjek historis. Perhatian utama ialah menemukan awal-awal dari legalitas hukum pertambangan sebagai sebuah diskursus kebijakan, menganalisa pluralitas sejarah kemunculannya secara faktual, dan melepaskan diri dari ilusi identitas subyek historis mengenai beberapa pengaturan terkait pertambangan rakyat, dimana dalam sejarahnya dimulai dari UU tentang pertambangan umum tahun 1967 dimana rakyat tidak memperoleh kesempatan sedikitpun dalam aktifitas pertambangan, kemudian UU Minerba tahun 2009 dan yang terakhir UU No. 3 tahun 2020 tentang perubahan UU Minerba tahun 2009, dimana secara yuridis Pemerintah Kabupaten/Kota tidak mempunyai kewenangan dalam hal pertambangan bahkan pertambangan rakyat.

Genealogi merupakan proses menganalisa dan menyingkap hubungan sejarah antara kebenaran, pengetahuan, dan kekuasaan, dimana pengetahuan dan kebenaran dihasilkan melalui perjuangan lalu dinyatakan sebagai abadi dan universal. Genealogi legalitas hukum pertambangan akan dipahami sebagai konstruksi sosial yang dihasilkan dari perjuangan dan pertarungan serta menghasilkan relasi kebenaran, pengetahuan dan kekuasaan, sebagaimana dijelaskan dalam bagan di bawah ini :

22 Andari, R. N. (2017). Evaluasi Kebijakan Penanganan Kejahatan Kekerasan Seksual terhadap Anak di Indonesia. Jurnal Ilmiah Kebijakan Hukum, 11(1), 1-11, p. 5 


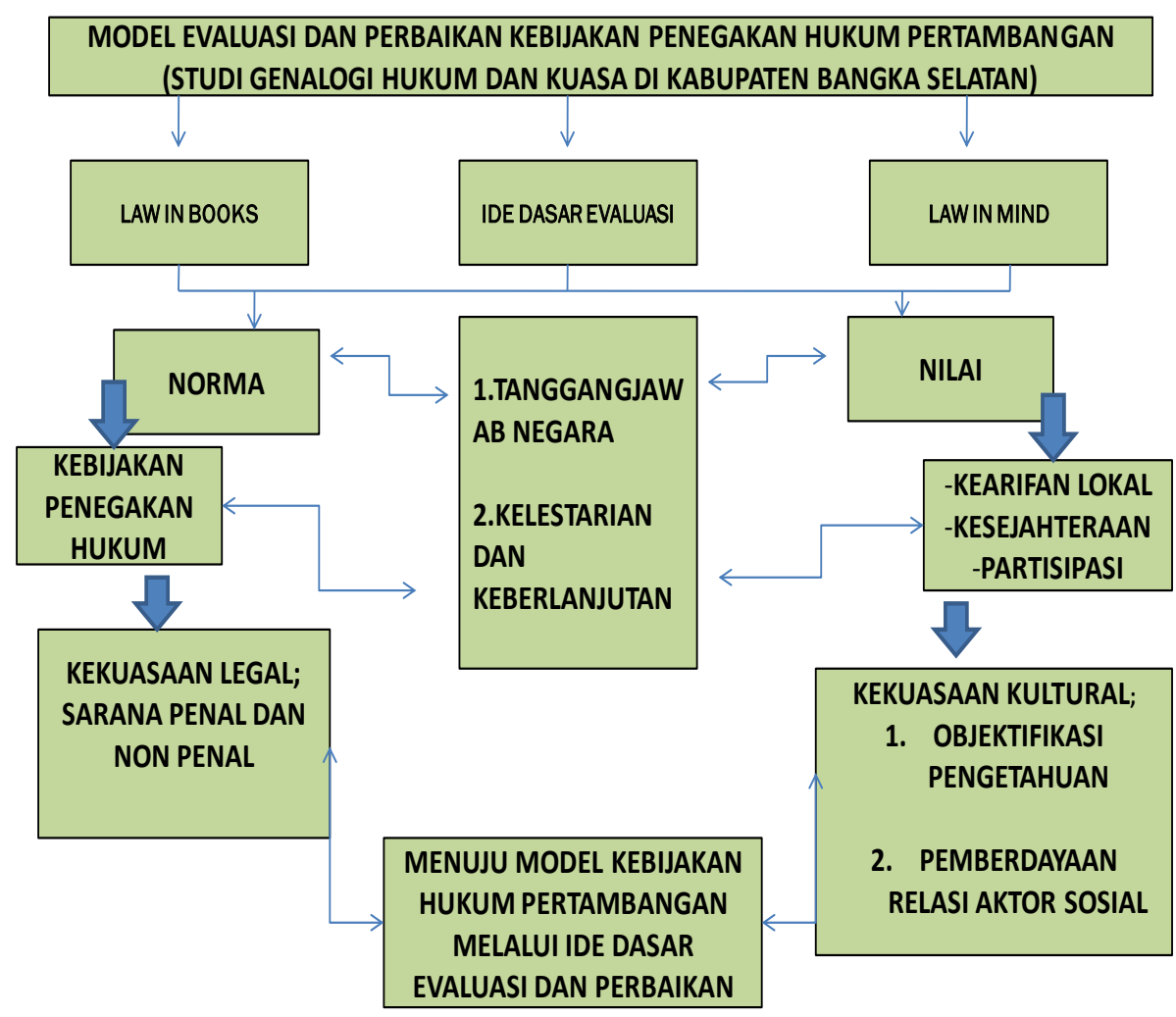

Bagan di atas mengintegrasi pendapat Foucault yang merubah diskursus yang telah mapan dalam memandang dan memahami kekuasaan. Pertama, kekuasaan tidak aja berada pada kondisi akan tetapi berada pada kondisi informal, dengan kata lain kekuasaan yang dimaksud berada pada kondisi tertentu; Kedua, sifat kekuasaan lebih ke arah produktif bukan hanya pada taraf represif; Ketiga, berjalannya sebuah kekuasaan dapat berhubungan pada relasi, instrumen dan kontak; Keempat, Negara memegang kekuasaan tertinggi dibandingkan dengan masyarakat sipil yang hanya memiliki kekuasaan dengan kadar terbatas; Kelima, kekuasaan adalah strategi. ${ }^{23}$

Sederhananya, kekuasaan dalam pandangan Foucault bersifat produktif, menghasilkan serangkaian pengetahuan (episteme) yang menggerakkan hidup manusia. Produk keilmuan dihasilkan oleh ilmuwan digerakkan oleh episteme tertentu; sehingga kemudian penjelasan perkembangan pemikiran hukum adalah episteme yang melingkupinya.

The law-maker must consider the process by which the actor chooses. A role-occupant who determines whether or not to obey a law secretly, without discussion with anyone, is plainly less likely to change his behaviour than one who can participate in public discussions that help formulateandpromulgatet he ruleitself. ${ }^{24}$

23 Marwan, A. (2010). Teori Hukum Kontemporer Suatu Pengantar Posmoderenisme Hukum. Yogyakarta: Rangkang Education, p. 53.

${ }^{24}$ Seidman, R. (1978). Why Do People Obey the Law? The Case of Corruption in Developing Countries. British Journal of Law and Society, 5(1), 45-68. doi:10.2307/1409847, p. 47. 


\section{Kesimpulan}

Urgensi evaluasi dan perbaikan kebijakan penegakan hukum pertambangan di Kabupaten Bangka Selatan dalam aspek legal, perizinan menjadi pintu masuk untuk melakukan evaluasi penegakan hukum pertambangan. Secara kontekstual fungsionalisasi kewenangan penindakan penegakan hukum pertambangan tidak terlepas dari faktor kekuasaan formal yang dimiliki aparatur hukum dan aparatur pemerintahan. Faktanya, penegakan yang dilakukan di satu tempat dan tempat yang lain terjadi perbedaan perlakuan, hal ini ditentukan oleh hubungan relasi penambang dengan struktur kekuasaan politik pemangku kebijakan dan dukungan dari kekuasaan sipil yang diyakini memiliki legitimasi pengamanan di lokasi tambang. Sehingga urgensi studi Geneologi terlibat dalam mengungkap relasi hukum dan kuasa di tengah kebijakan penegakan hukum pertambangan di Kabupaten Bangka Selatan yang masih dirasakan tidak sesuai dengan prinsip-prinsip persamaan di depan hukum, kepastian hukum, dan keadilan hukum.

Model evaluasi dan perbaikan kebijakan penegakan hukum pertambangan merupakan bagian penting untuk melakukan proses mewujudkan model evaluasi dan perbaikan kebijakan penegakan hukum pertambangan di Kabupaten Bangka Selatan yang berpijak pada ide dasar tanggungjawab negara dan kelestarian serta keberlanjutan lingkungan. Penegakan hukum pertambangan di Kabupaten Bangka Selatan mestinya berpijak pada ide dasar tersebut dalam menerapkan norma hukum baik itu dengan sarana penal dan non-penal. Aspek nilai juga merupakan bagian penting dalam model dan evaluasi agar dapat memperhatikan kearifan lokal, kesejahteraan, serta partisipasi relasi aktor sosial masyarakat.

\section{Ucapan terima Kasih (Acknowledgments)}

Ucapan terima kasih diberikan kepada Lembaga Penelitian dan Pengabdian Kepada Masyarakat Universitas Bangka Belitung yang telah mendanai kegiatan ini melalui skim Penelitian Dosen Tingkat Universitas (PDTU) tahun 2020

\section{Daftar Pustaka}

\section{$\underline{\text { Buku }}$}

Marwan, A. (2010). Teori Hukum Kontemporer Suatu Pengantar Posmoderenisme Hukum. Yogyakarta: Rangkang Education.

Supramono, G. (2012). Hukum Pertambangan Mineral dan Batu Bara di Indonesia. Rineka Cipta.

Haryatmoko, J. (2016). Etika Politik dan Kekuasaan. Kompas.

Sembiring, S. F. (2009). Jalan baru untuk tambang: mengalirkah berkah bagi anak bangsa. Elex Media Komputindo.

Philpott, S. (2007). Meruntuhkan Indonesia "Politik Postkolonial dan Otoritarianisme", Yogyakarta, LKIS.

Latif, Y. (2013). Genealogi Intelegensia Pengetahuan dan Kekuasaan Intelegensia Muslim Indonesia Abad XX. Jakarta: Kencana. 


\section{Journal}

A. Widyarsono, (1999) Hubungan Kuasa dan Pengetahuan Menurut Foucault Jurnal Filsafat Driyarkara, Tahun XXI, No. 4.

Redi, A. (2016). Dilema Penegakan Hukum Penambangan Mineral Dan Batubara Tanpa Izin Pada Pertambangan Skala Kecil. Jurnal Rechts Vinding: Media Pembinaan Hukum Nasional, 5(3), 399-420. DOI: http://dx.doi.org/10.33331/rechtsvinding.v5i3.152

Rahayu, D. P., \& Faisal, J. C. (2019). Rekonstruksi Partisipasi Masyarakat Dalam Perizinan Pertambangan Rakyat Berbasis Nilai Kearifan Lokal (Studi Kasus Izin Pertambangan Rakyat di Kabupaten Belitung Timur). In Prosiding Seminar Hukum dan Publikasi Nasional (Serumpun) (Vol. 1, No. 1, pp. 446-457).

Rahayu, D. P., \& Faisal, F. (2020). Legal of Permission Folk Mining in Indonesia. Wacana Hukum, 26(1), 49-54. DOI: http://dx.doi.org/10.33061/1.wh.2020.26.1.3630

Rahayu, D. P., Pujirahayu, E. W., \& Samekto, F. A. (2018, July). Institutional Territory on Folk Mining in Indonesia. In IOP Conference Series: Earth and Environmental Science (Vol. 175, No. 1, p. 012186). IOP Publishing. DOI: https://doi.org/10.1088/1755-1315/175/1/012186

Butar, F. B. (2010). Penegakan Hukum Lingkungan di Bidang Pertambangan. Yuridika, 25(2), 151-168 doi: http://dx.doi.org/10.20473/ydk.v25i2.252

Isdiyanto, I. Y. (2018). Menakar "Gen” Hukum Indonesia Sebagai Dasar Pembangunan Hukum Nasional. Jurnal Hukum \& Pembangunan, 48(3), 589-611. DOI: http://dx.doi.org/10.21143/jhp.vol48.no3.1747

Mai, M., \& Saputra, E. B. (2018). Penegakan Hukum Terhadap Tindak Pidana Pertambangan Batuan Non Logam Pada Tanah Hak Milik Masyarakat (Studi Pada Satreskrim Polres Kerinci). UNES Law Review, 1(1), 70-80. DOI: https://doi.org/10.31933/law.v1i1.7

Seidman, R. (1978). Why Do People Obey the Law? The Case of Corruption in Developing Countries. British Journal of Law and Society, 5(1), 45-68. doi:10.2307/1409847.

Andari, R. N. (2017). Evaluasi Kebijakan Penanganan Kejahatan Kekerasan Seksual terhadap Anak di Indonesia. Jurnal Ilmiah Kebijakan Hukum, 11(1), 1-11.

Budiman, S. (2017). Analisis Hubungan antara Hukum dan Kebijakan Publik: Studi Pembentukan UU No. 14 Tahun 2008. Jurnal Ilmiah Kebijakan Hukum, 11(2), 109119. DOI: http://dx.doi.org/10.30641/kebijakan.2017.V11.109-119.

Parsons, W. (2004). Not just steering but weaving: Relevant knowledge and the craft of building policy capacity and coherence. Australian journal of public administration, 63(1), 43-57. DOI: $\quad$ https://doi.org/10.1111/j.14678500.2004.00358.x

Hefni, W. (2018). Genealogi Studi Hukum Islam di Perguruan Tinggi Keagamaan Islam Indonesia. Al-Ihkam: Jurnal Hukum dan Pranata Sosial, 13(1), 226-230. DOI: http://dx.doi.org/10.19105/al-ihkam.v13i1.1788.

Prianto, Y., Djaja, B., Rasji, S. H., \& Gazali, N. B. (2019). Penegakan Hukum Pertambangan Tanpa Izin Serta Dampaknya Terhadap Konservasi Fungsi Lingkungan Hidup. Bina Hukum Lingkungan, 4(1), 1-20. DOI: http://dx.doi.org/10.24970/bhl.v4i1.80 


\section{Peraturan Perundang-undangan}

Undang-Undang No. 1 tahun 1967 tentang Pengelolaan Pertambangan Umum

Undang-Undang No. 4 tahun 2009 tentang Mineral Batubara

Undang-Undang No. 3 tahun 2020 tentang Perubahan UU No. 4 tahun 2009 tentang Mineral Batubara

Undang-Undang No. 23 tahun 2014 mengenai Pemerintah Daerah

Undang-undang No. 32 tahun 2009 tentang Pengelolaan dan Pelestaerian Lingkungan Hidup.

\section{Internet}

Aston. (2019). Submerged by TI Waste, Hundreds of Pariadi's Rubber Trees Threatened to Death. Available online from: https://wowbabel.com/2019/12/26/terendam-limbah-tiratusan-pohon-karet-milik-pariadi-terancam-mati, [Accessed March 7, 2020].

Jhoni Kurniawan. (2020). Not Alert Warning, Satpol PP Bangka Selatan Not Immediately Burn IT Illegal. Available online from: https://bangka.tribunnews.com/2020/03/09/tak-indahkan-peringatan-satpol-pp-bangkaselatan-tak-segan-bakar-ti-ilegal. [Accessed March 10, 2020]. 